\title{
Selective retention of two dinoflagellates in a well- mixed estuarine embayment: the importance of diel vertical migration and surface avoidance*
}

\author{
D. M. Anderson ${ }^{1} \&$ K. D. Stolzenbach ${ }^{2}$ \\ ${ }^{1}$ Biology Department, Woods Hole Oceanographic Institution, Woods Hole, Massachusetts 02543, USA \\ ${ }^{2}$ Department of Civil Engineering, Massachusetts Institute of Technology, Cambridge, Massachusetts 02139, USA
}

\begin{abstract}
Diel vertical migration patterns of the dinoflagellates Gonyaulax tamarensis and Heterocapsa triquetra were monitored in an estuarine embayment subject to localized blooms of both species. A concurrent study of tidal flushing using a dye tracer demonstrated an efficient, densitydriven mixing process that exchanged water within the embayment at a rate of approximately $0.5 \mathrm{~d}^{-1}$. Loss rates of the whole pond populations of $G$. tamarensis and $H$. triquetra cells were smaller, ranging between 0.02 and $0.13 \mathrm{~d}^{-1}$. The cells were thus able to maintain a non-mixed distribution even under weakly stratified conditions. This selective retention of the 2 species relative to water exchange was due to the differential advection of surface and bottom waters through the inlet channel and the general avoidance of high irradiance surface layers by the dinoflagellates. Both species migrated to irradiances equivalent to $30 \%$ of summer sunlight when nutrients were presumably non-limiting, resulting in subsurface aggregations 1 to $2 \mathrm{~m}$ deep. Under nutrient-limited conditions, G. tamarensis migration was restricted to irradiance at or below 10 to $15 \%$ summer sunlight. Planozygotes (a life-cycle stage preceding cyst formation) migrated in a manner indistinguishable from the remainder of the nutrientlimited $G$. tamarensis population. The results help to explain the dominance of dinoflagellates in such embayments, the localization of their blooms, and the distribution of their resting cysts in the region.
\end{abstract}

\section{INTRODUCTION}

Diel vertical migration of marine and freshwater dinoflagellates has been the subject of numerous field and laboratory investigations. Both phototaxis (Forward 1976) and geotaxis (Eppley et al. 1968, Cullen \& Horrigan 1981) have been invoked to explain the directionality of swimming behavior, with a variety of physical and chemical factors regulating the extent of vertical movement. These include nutrients (Eppley et al, 1986, Cullen \& Horrigan 1981, Heaney \& Eppley 1981); light intensity (Harris et al. 1979, Heaney \& Talling 1980); temperature or salinity gradients (Seliger et al. 1970, Kamykowski \& Zentara 1977. Tyler \& Seliger 1978, 1981); and oxygen availability (Heaney 1976, George \& Heaney 1978). It is now clear that individual species can respond differently to these parameters (Eppley et al. 1968, Heaney \& Eppley 1981)

\footnotetext{
- Contribution No. 5885 from the Woods Hole Oceanographic Institution
}

and that the response to one factor can be influenced by others. Heaney \& Eppley (1981) provide an example of the complex migration patterns that can arise when dinoflagellates are exposed to simultaneous variations in nutrients, light, and temperature in the laboratory.

There are several important benefits or impacts associated with vertical migration. The most commonly cited advantage is that of access to nutrients located below the depleted surface layers in stratified waters (Holmes et al. 1967, Eppley et al. 1968, Eppley \& Harrison 1975, MacIsaac 1978). Another impact is that the vertical accumulation of individual cells may determine the horizontal distribution of the population as a whole. If the cells aggregate at specific depths, possibly due to the suppression of phototaxis at sharp salinity gradients (Seliger et al. 1970, Tyler \& Seliger 1981 ) or to the selection of an optimal light environment (George \& Heaney 1978, Heaney \& Talling 1980), differential movement of water layers due to wind stress or 2-layer estuarine flow can then selectively transport the populations horizontally (Seliger et al. 
1970, Heaney \& Talling 1980, Tyler \& Seliger 1981). In all cases, a well-stratified water column has been a prerequisite for the differential horizontal motion.

In this study we describe the role of vertical migration in limiting the horizontal transport and advective losses of 2 dinoflagellates in an estuarine embayment. Heterocapsa triquetra is an ecologically successful organism that often dominates the phytoplankton in estuarine and coastal waters; Braarud \& Pappas (1951) document the phototactic behavior of this species in culture vessels but there are no quantitative field or laboratory studies to describe the swimming patterns in more detail. Gonyaulax tamarensis (= Protogonyaulax tamarensis; Taylor 1979), is the toxic dinoflagellate responsible for outbreaks of paralytic shellfish poisoning in many parts of the world; blooms of this species in the coastal zone are often manifest in subsurface accumulations along frontal boundaries separating tidally-mixed and stratified waters (Yentsch 1984). Swimming behavior is clearly important in the formation of these subsurface patches, yet nothing is known of this dinoflagellate's response to the vertical distribution of light and nutrients. $G$. tamarensis also thrives in estuarine environments (Anderson \& Morel 1979, Schrey et al. 1984, Yentsch 1984) where the rate of tidal exchange can approximate the dinoflagellate's maximum growth rate (Garcon et al. unpubl.j. Recurrent toxic blooms in these locations could only result from the selective retention of the cells relative to the ebbing seawater, but the mechanisms underlying the retention are unknown.

In this paper we describe the vertical migration behavior of these 2 species in Salt Pond, an embayment typical of many within the Cape Cod region that are often dominated by dinoflagellates (Hulburt 1956). In conjunction with a dye experiment to trace water mixing and circulation patterns, the results make it possible to assess the differential advective loss rates of water and cells during tidal exchange and the importance of vertical migration behavior in this process.

\section{METHODS}

Study area. Salt Pond (Eastham, Massachusetts) is a circular embayment $82,200 \mathrm{~m}^{2}$ in area with average and maximum depths of approximately 3.4 and $7 \mathrm{~m}$ respectively at slack low tide (Fig. 1). There are no stream or river inputs of freshwater but groundwater does enter the pond via springs. A shallow inlet channel $(0.5 \mathrm{~km}$ long, $30 \mathrm{~m}$ wide, $0.5 \mathrm{~m}$ deep at low tide) allows tidal exchange with a large salt marsh system that connects to the ocean at Nauset.

Vertical cell distributions. On May 30 and 31, 1980. June 4 and 5, 1981, and May 25 and 26, 1983, the

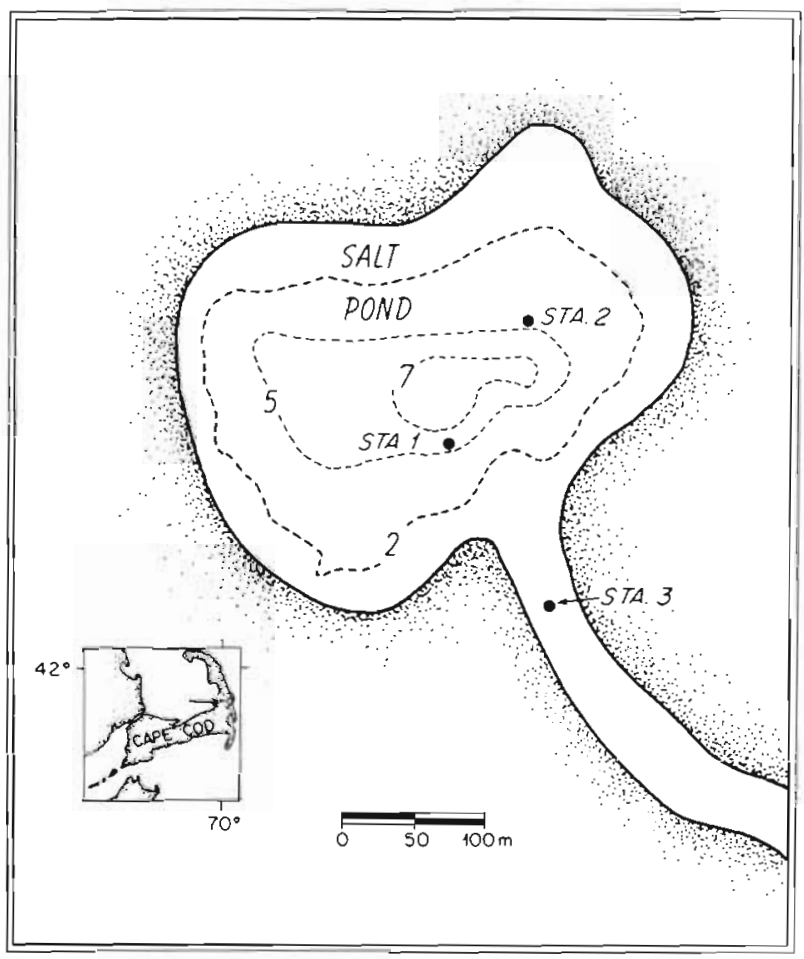

Fig. 1. Map of Salt Pond, Eastham, Massachusetts (USA) with sampling stations. Contours are in m at slack low tide

vertical distribution of Gonyaulax tamarensis cells was determined at Station 1 (Fig. 1) along with associated measurements of nutrients (1980, 1981 only), irradiance, salinity, and temperature. Heterocapsa triquetra distributions were recorded in 1981 and 1983 only. During 1980 and 1981, vertical sampling was accomplished using $50 \mathrm{ml}$ plastic syringes mounted at $10 \mathrm{~cm}$ intervals on a frame (Heaney 1974). The weighted unit was lowered with all syringe plungers fully inserted but under tension from stretched sections of surgical tubing. The tension was released and the syringes filled simultaneously when the rope attached to the locking mechanism was pulled. The unit was taken from the water, the samples dispensed, the syringes reloaded, and the process repeated at lower depths. A maximum of 3 deployments were needed for each profile. Since the syringes were about $10 \mathrm{~cm}$ apart and separate syringes were used for cell counts, nutrients, and salinity, the data are reported at different vertical intervals. Profiles of irradiance (PAR, 400 to $700 \mathrm{~nm}$ ) were made with a Li Cor flat plate (cosine) quantum sensor (LI-192S) at $0.5 \mathrm{~m}$ intervals in 1980 , and with a Biospherical Instruments spherical (scalar) sensor (QSP-200) in 1981 and 1983. Temperature profiles were obtained with a YSI Model 33 S-C-T meter.

In 1983, the sampling procedure was changed to a pumping system that used lengths of Tygon tubing differing by $0.5 \mathrm{~m}$ that were tied together, weighted, 
and suspended from a floating rubber tire tube. A DC pump (Fluid Metering, Inc., Model RP) powered with a 12 volt battery was connected to the end of each tube in succession and a sample collected after sufficient time for flushing and rinsing. Samples for cell counts, salinity and dye were collected in this way, and profiles of irradiance and temperature taken as described above. Cell count and irradiance data were collected at $3 \mathrm{~h}$ intervals and the other parameters hourly. Similar profiles of salinity, temperature, and dye concentration were collected hourly with the pumping system and temperature probe at a second station (Sta. 2: Fig. 1) to provide additional information on water circulation. A $20 \%$ rhodamine WT dye solution was injected at a rate of $3 \mathrm{ml} \mathrm{min} \mathrm{min}^{-1}$ during the flood tide using a batteryoperated peristaltic pump. The injection point was 250
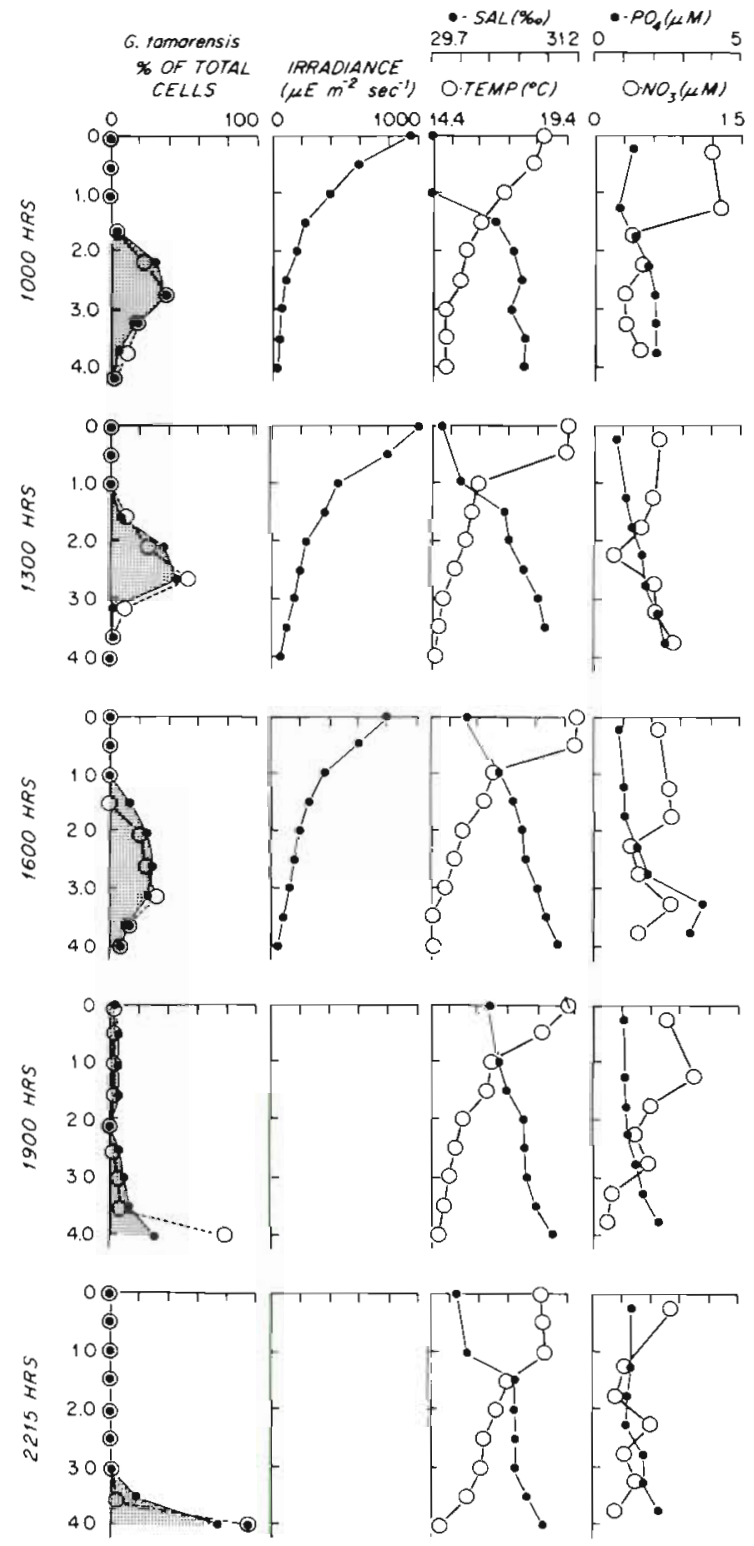

m from the entrance to Salt Pond in the center of the inlet channel.

At hourly intervals, temperature, salinity, dye (1983 only) and Gonyaulax tamarensis and Heterocapsa triquetra cell concentrations were determined at the inlet (Sta. 3: Fig. 1). Samples were collected by pumping into a bucket while a weighted tube was slowly lowered to the bottom. Other samples for cell counts were collected at the beginning of each migration study at 20 stations spaced uniformly around Salt Pond. Surface-to-bottom integrated samples were collected at each station using the pumping system. Cell concentrations were totalled by taking the average depth of each sector into account, providing estimates of the total $G$. tamarensis and $H$. triquetra populations in the embayment at the start of each study. All cell count
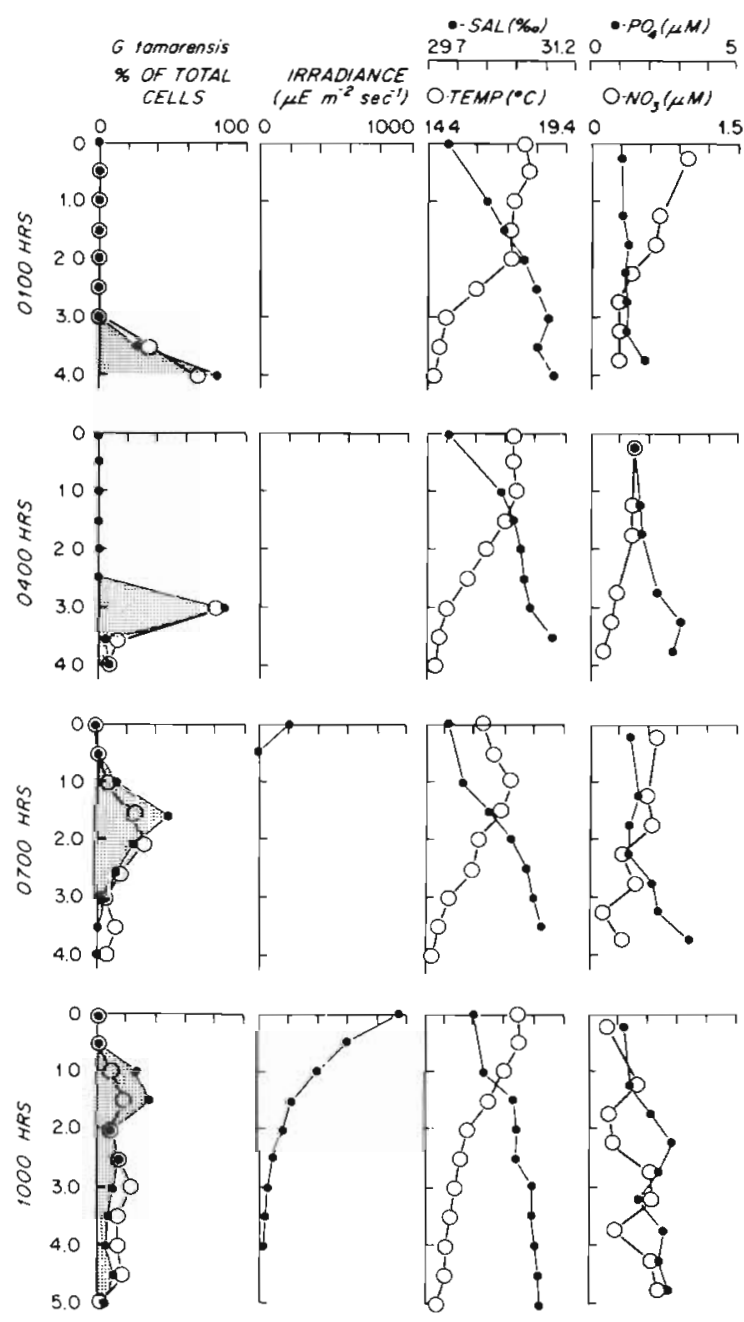

Fig. 2. Vertical profiles for 1980 study. Shaded areas: Gonyaulax tamarensis total population, distinguished from $G$. tamarensis planozygotes $(0-\infty)$ ). Ordinate: depth in $\mathrm{m}$ for all panels. Irradiance measured with cosine collector 
samples were fixed with Utermöhl's solution, settled in a $50 \mathrm{ml}$ chamber, and enumerated with an inverted microscope. A minimum of 200 cells were counted for each sample. When present, $G$. tamarensis planozygotes were tabulated separately based on the criteria of Anderson et al. (1983). Nutrient samples were filtered as they were dispensed from the syringes through Whatman GFF glass fiber filters, frozen, and analysed at a later date using the methods of Strickland \& Parsons (1972). Dye concentrations were measured with a Turner Designs Model 10 fluorometer with a rhodamine filter set. Unreferenced tidal elevations were determined using frequent observations of meter sticks placed in the inlet channel. Tidal volumes were calculated using the average elevation at $15 \mathrm{~min}$ intervals and the average pond surface area. These were then totalled over each tidal phase and expressed as a percent of low tide volume.

\section{RESULTS}

\section{0 study}

Salt Pond was moderately stratified, with temperature and salinity differences between surface and bot- tom waters of 3 to $5 \mathrm{C}^{\circ}$ and 0.2 to $0.5 \%$ respectively and density varying by $2 \sigma_{t}$ units (Fig. 2). The surface was always warmer and less saline than the waters below. Tidal range was about $1 \mathrm{~m}$, with ebb flow beginning several hours before midnight and noon. The pond filled rapidly on the flood tide $(4 \mathrm{~h})$, but took nearly $8 \mathrm{~h}$ to drain. Between 18 and $22 \%$ of the low tide volume entered or left the pond with each tidal phase, equivalent to a maximum potential plug flow flushing rate of $0.40 \mathrm{~d}^{-1}$ (Table 1). The weather was sunny with scattered clouds and 5 to 10 knot southerly winds. Sunrise was at 0500 and sunset at $1930 \mathrm{~h}$.

A distinct vertical migration pattern was observed for the Gonyaulax tamarensis population (Fig. 2). Approximately $30 \%$ of the cells were planozygotes (large, deeply pigmented swimming cells that become cysts) but their migration behavior was the same as that of the population as a whole. During the migration: (d) cells avoided the top 1.5 in of water, even during midday hours; (b) maximum irradiance reached by the population peak was approximately $200 \mu \mathrm{E} \mathrm{m} \mathrm{m}^{-2}$ $\mathrm{s}^{-\mathrm{I}}$ (measured with a cosine collector); (c) vertical movement of the population peak through time corresponded to a swimming speed of 0.5 to $0.75 \mathrm{~m} \mathrm{~h}^{-1}$; (d) cells began their ascent before sunrise, and their descent before sunset; (e) $\mathrm{NO}_{3}^{-}$and $\mathrm{PO}_{4}^{3-}$ concentrations

Table 1. Water volume and dinoflagellate cells gained or lost during tidal fluctuations

\begin{tabular}{|c|c|c|c|c|c|}
\hline \multirow[t]{2}{*}{ Year } & \multirow[t]{2}{*}{ Tidal stage } & \multirow[t]{2}{*}{ Photoperiod } & \multirow{2}{*}{$\begin{array}{l}\% \text { of low tide } \\
\text { volume }\end{array}$} & \multicolumn{2}{|c|}{$\%$ of total population lost or gained $\cdots$} \\
\hline & & & & G. tamarensis & H. triquetra \\
\hline \multicolumn{6}{|l|}{1980} \\
\hline & Ebb & Light & -18.1 & -8.4 & \\
\hline & Flood & Dark & +22.6 & +0.6 & \\
\hline & Ebb & Dark & -22.3 & -0.3 & \\
\hline & Flood & Light & +19.4 & +0.3 & \\
\hline \multicolumn{6}{|c|}{ Net 24 h change } \\
\hline \multicolumn{6}{|l|}{1981} \\
\hline & Flood & Light & +29.0 & +1.0 & +0.9 \\
\hline & $\mathrm{Ebb}$ & Light & -29.1 & -7.0 & -0.4 \\
\hline & Flood & Dark & +40.2 & +0.2 & +1.9 \\
\hline & Ebb & Dark/light & -40.0 & -6.9 & -0.6 \\
\hline & Flood & Light & +29.0 & $+\underline{0.1}$ & +1.1 \\
\hline \multicolumn{6}{|c|}{ Net 24 h change } \\
\hline \multicolumn{6}{|l|}{1983} \\
\hline & Flood & Light & +20.7 & +1.2 & +4.9 \\
\hline & Ebb & Light & -19.8 & -1.7 & -3.9 \\
\hline & Flood & Dark & +24.2 & +0.5 & +45 \\
\hline & Ebb & Dark/light & -21.0 & $=1.9$ & -4.6 \\
\hline \multicolumn{6}{|c|}{ Net 24 h change } \\
\hline $\begin{array}{l}\text { - Change } \\
\text { tidal sta } \\
\cdots \text { Inlet cel } \\
\text { over tha }\end{array}$ & $\begin{array}{l}\text { d volume as } \\
\text { as a percen } \\
\text { tage }\end{array}$ & $\begin{array}{l}\text { ent of low tide } \\
\text { al Salt Pond pop }\end{array}$ & $\begin{array}{l}\text { Plus and minus signs signi } \\
\text { at low tide. Plus and minus }\end{array}$ & $\begin{array}{l}\text { hify gains and los } \\
\text { Is signs signify } 9\end{array}$ & $\begin{array}{l}\text { f water over that } \\
\text { and losses of cells }\end{array}$ \\
\hline
\end{tabular}


remained at or above $0.5 \mu \mathrm{M}$ but were highly variable in vertical distribution.

The time course of advective loss of water and dinoflagellates from Salt Pond due to tidal fluctuations is shown in Table 1. During daylight hours, $8.4 \%$ of the whole pond population of Gonyaulax tamarensis was removed with the ebb tide. Only $7 \%$ of the advected cells returned when the tide reversed (equivalent to $0.6 \%$ of the total pond population). The ebb tide at night carried fewer cells from the pond $(0.3 \%)$. The $24 \mathrm{~h}$ advective loss of $G$. tamarensis from Salt Pond was $7.8 \%$.

\section{1 study}

Weather conditions were similar to the 1980 study, but Gonyaulax tamarensis cells migrated differently. With scattered clouds and 7 to 10 knot westerly winds, the water was moderately stratified with nearly $2 \sigma_{1}$ units difference between the surface and bottom (Fig. 3). Spring tide fluctuations were semi-diurnal and large, with a $1.5 \mathrm{~m}$ elevation on the first flood and $2.5 \mathrm{~m}$ on the second. Ebb tide occurred late in the day near $1500 \mathrm{~h}$ and again near $0330 \mathrm{~h}$ (Fig. 4). Sunrise and sunset were at 0500 and $1900 \mathrm{~h}$, respectively. Between
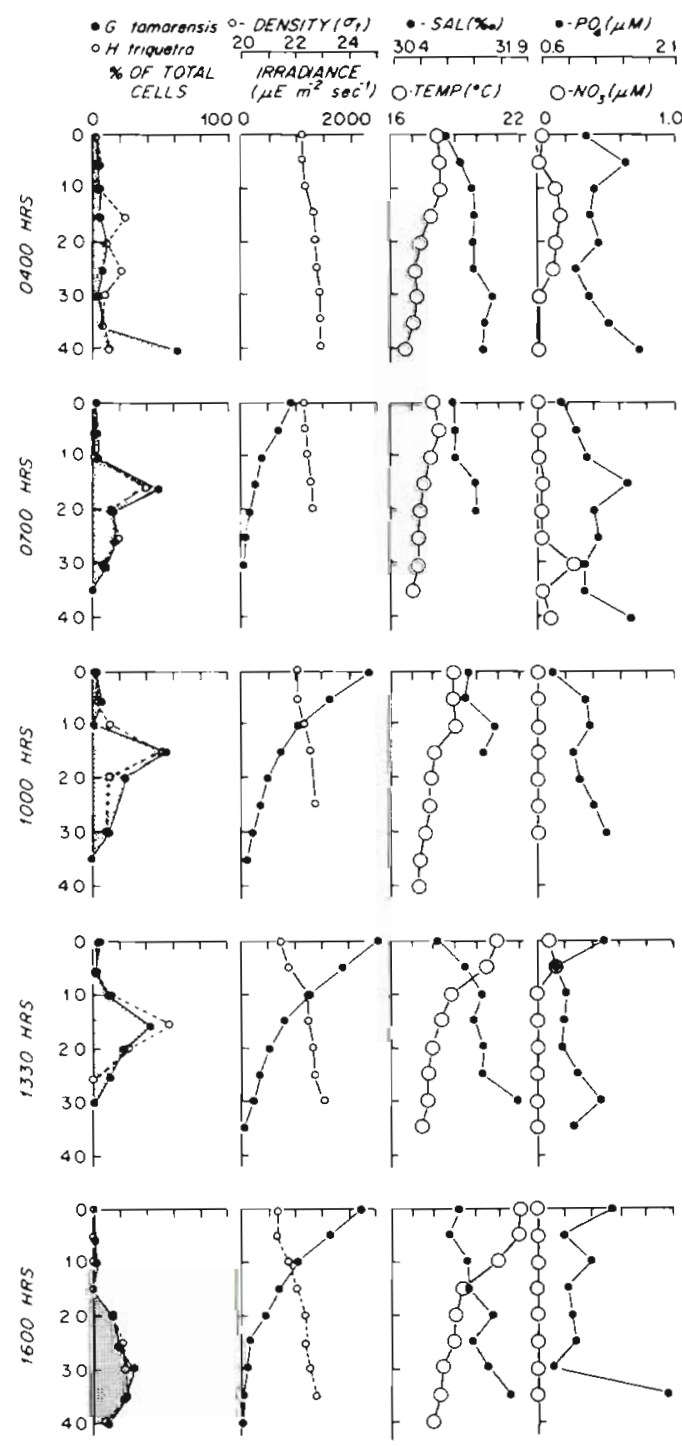

Fig. 3. Vertical profiles for 1981 study. Shaded areas: Gonyaulax tamarensis total population, distinguished from Heterocapsa triquetra $(0--0)$. Ordinate: depth in $\mathrm{m}$ for all panels. Irradiance measured with scalar sensor 

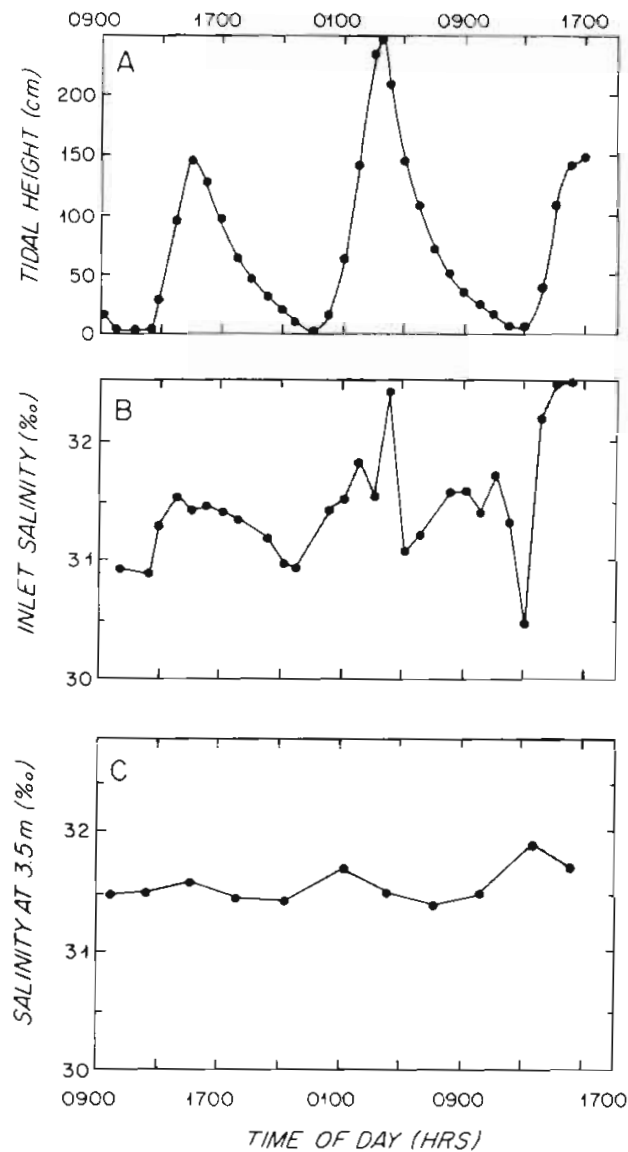

Fig. 4. Tidal elevation and salinity measurements for 1981 study. Shaded area: flood tide interval. (A) Tidal elevation; (B) Inlet salinity, Station $3 ;$ (C) Salinity at $3.5 \mathrm{~m}$. Station 1

29 and $40 \%$ of the low tide volume entered or left the pond with each tidal phase, equivalent to a potential flushing rate of nearly $0.70 \mathrm{~d}^{-1}$ (Table 1 ).

Salinity measurements at the inlet demonstrate that water flowing into the pond was typically more saline than that already present (Fig, 4 B). A slight increase in salinity at $3.5 \mathrm{~m}$ at Station 1 was observed with each flood tide (Fig. 4 C).

The 1981 Gonyaulax tamarensis population contained no planozygotes, even though $\mathrm{NO}_{3}^{-}$concentrations were low. (Ammonium concentrations were not measured.) During the preceding week, $\mathrm{NO}_{3}^{-}$concentrations averaged $1.2 \mu \mathrm{M}$ (Anderson et al, 1983). Details of the migration pattern include: (a) $G$. tamarensis consistently avoided the top meter of the water column; (b) maximum level of the population peak was 750 to $850 \mu \mathrm{E} \mathrm{m}^{-2} \mathrm{~s}^{-1}$ (scalar collector); (c) swimming speeds ranged between 0.6 and $0.7 \mathrm{~m} \mathrm{~h}^{-1}$; (d) cells began their descent before sunset; (e) population losses during ebb tides were near $7 \%$, with few cells returning with the flood (Table 1). Net daily loss of $G$. tamarensis from the pond was $12.9 \%$.
Although more broadly dispersed vertically, the Heterocapsa triquetra population migrated in a manner similar to that of co-occurring Gonyaulax tamarensis (Fig. 3). Maximum irradiance for the population peak was 750 to $850 \mu \mathrm{E} \mathrm{m} \mathrm{m}^{-2} \mathrm{~s}^{-1}$ as the cells consistently avoided the surface. Relatively few $H$. triquetra cells left or entered the pond with tidal flow, ranging between 0.4 and $1.9 \%$ of the total pond population during one tidal stage (Table 1).

\section{3 study}

In addition to the parameters monitored in previous years, the 1983 study used rhodamine dye to track water movement. The water column was weakly stratified, with only fractional differences in $\sigma_{t}$ from surface to bottom (Fig. 5). Surface waters were, on average, less dense than bottom waters however. The weather was initially clear with broken clouds and 6 to 10 knot southerly winds, turning to overcast the morning of the second day. Ebb tides began shortly after noon and midnight, starting from a 1.2 to $1.5 \mathrm{~m}$ tidal elevation (Fig. 6). Sunrise was at $0515 \mathrm{~h}$ and sunset at $1930 \mathrm{~h}$. Tidal flows were 20 to $24 \%$ of low tide volume, equivalent to a potential flushing rate of $0.45 \mathrm{~d}^{-1}$ (Table 1). Inlet salinities varied broadly with no apparent trends (Fig, 6).

Dye concentrations measured at the inlet showed an initial pulse from the injection and then a rapid decrease to a relatively constant 0.35 ppb (Fig. 6 C). At Station 1 , the dye first appeared at the surface at 1030 $h$, but when the flood tide ended at $1300 \mathrm{~h}$ the highest rhodamine concentrations were at depth (Fig. 5). Vertical dye distribution gradually became more uniform. resembling a well-mixed system by midnight. A similar pattern (not shown) was observed from hourly dye measurements at Station 2 in the pond. Also not shown are hourly dye measurements at Station 1 which are consistent with the general patterns depicted using $3 \mathrm{~h}$ intervals in Fig. 5. The volume-weighted vertical average of the dye concentrations at Stations 1 and 2 for each sampling interval gradually decreased through time. A ln-linear regression (dye concentration versus time) gave a slope significantly different from zero ( $P$ $<.05$ ) and a dye removal rate of $0.46 \mathrm{~d}^{-1}$, both stations combined.

In 1983, both planozygotes and vegetative cells of Gonyaulax tamarensis were present. During the migration: (a) cells consistently avoided the surface, stopping their vertical movement 1 to $2 \mathrm{~m}$ deep; (b) maximum irradiance received by the population peak was $300 \mu \mathrm{E} \mathrm{m}^{-2} \mathrm{~s}^{-1}$ (scalar sensor) ; (c) vertical movement was $0.7 \mathrm{~m} \mathrm{~h}^{-1}$ i (d) cells began their descent before sunset; (e) loss rates of cells during ebb tides were 

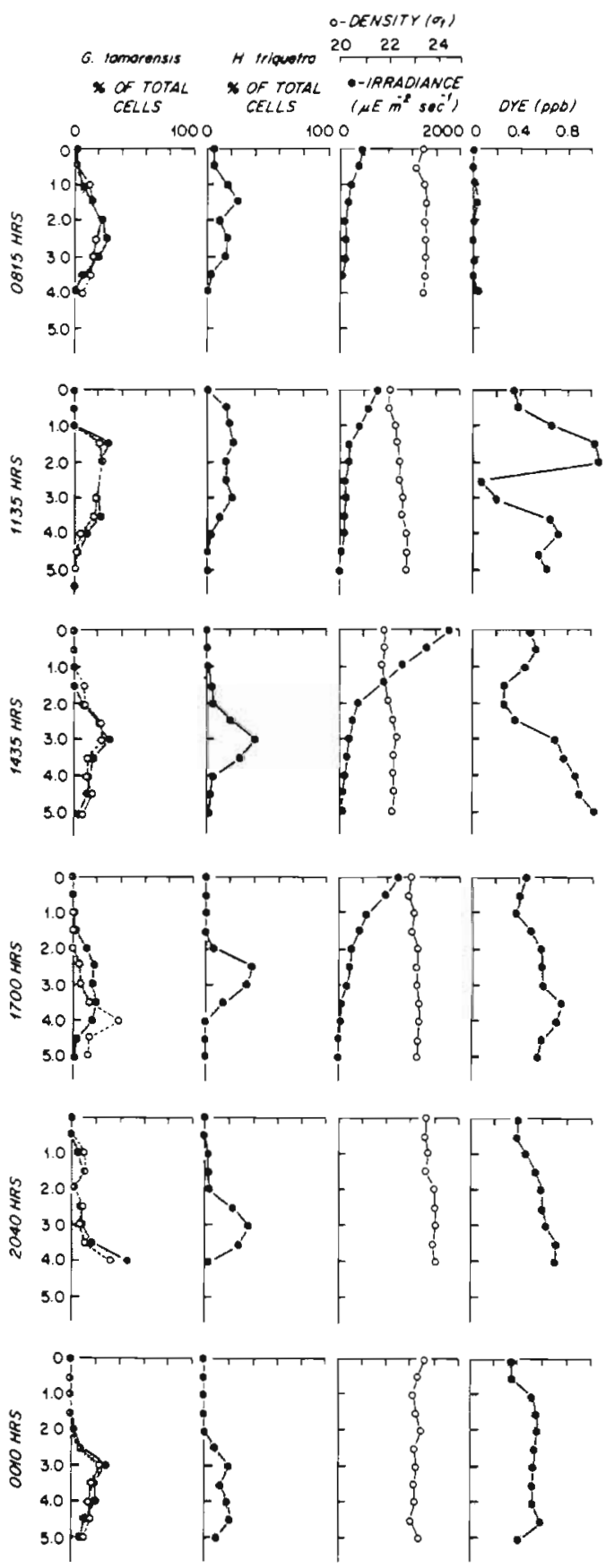

small (0.5 and $1.2 \%)$. The daily population loss from the pond was $2 \%$ (Table 1 ).

Heterocapsa triquetra consistently migrated higher in the water column than Gonyaulax tamarensis during 1983, with irradiance levels for the population peak of $700 \mu \mathrm{E} \mathrm{m}^{-2} \mathrm{~s}^{-1}$. Timing and rate of migration were otherwise similar for the 2 species. Since the morning of Day 2 was overcast, $H$. triquetra did enter the top meter of the water column in significant numbers. However, timing of the tide and migration were
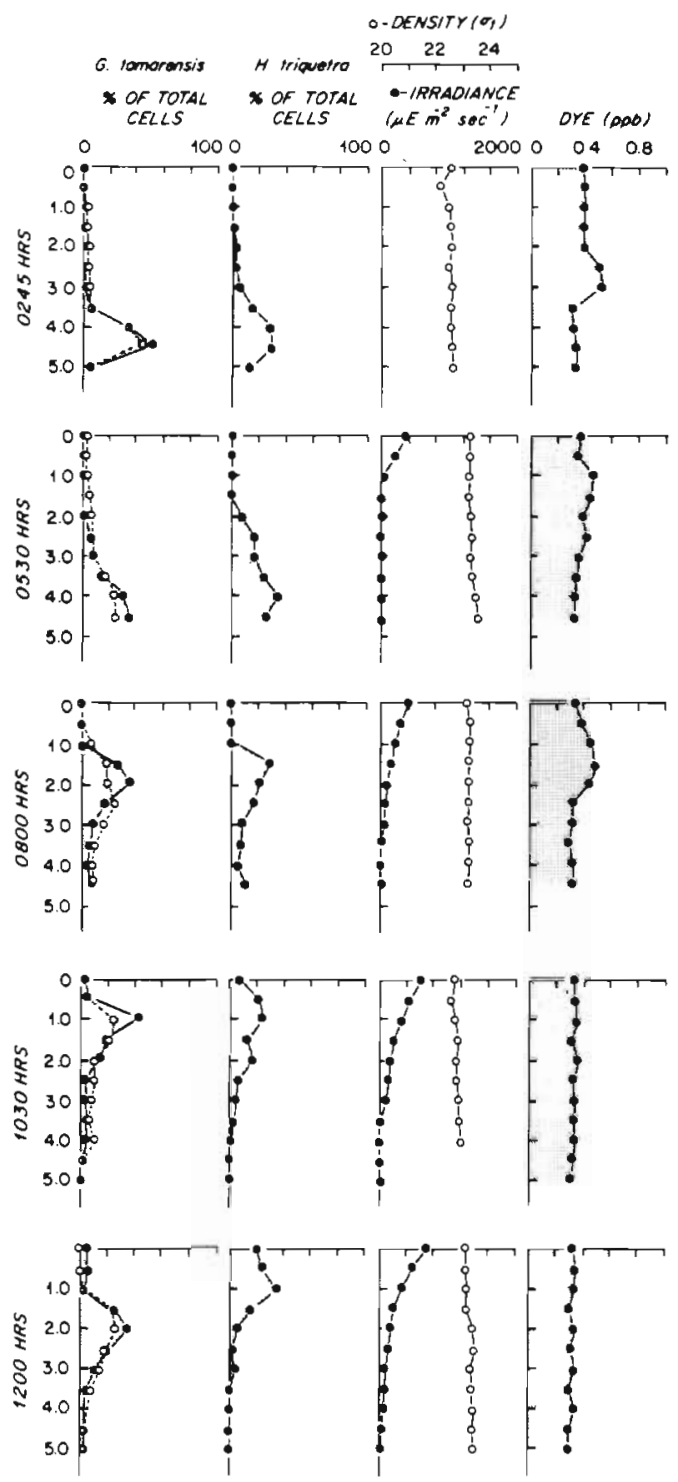

Fig. 5. Vertical profiles for 1983 study. In Gonyaulax tamarensis column, shaded areas: total population, distinguished from planozygotes $(0 \ldots-0)$. Ordinate: depth in $m$ for all panels. Irradiance measured with scalar sensor

such that relatively few cells were lost with ebb flow. Population losses and gains were both 4 to $5 \%$ per tidal stage for a net gain of $0.9 \%$ over $24 \mathrm{~h}$.

\section{DISCUSSION}

Both Heterocapsa triquetra and Gonyaulax tamarensis demonstrated diel vertical migration behavior under natural bloom conditions, with the pattern of 

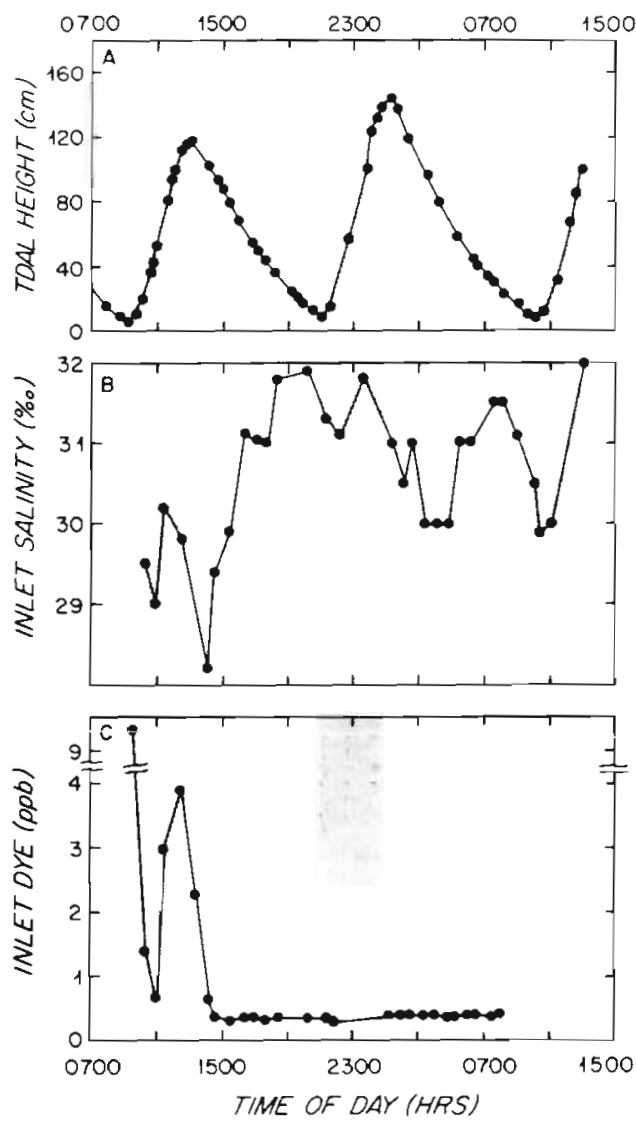

Fig. 6. Tidal elevation, salinity and dye measurements for 1983 study. Shaded area: flood tide interval. (A) Tidal elevation; (B) Inlet salinity; (C) Inlet dye concentration

these migrations differing between species and for the same species through time. The dinoflagellates were selectively retained relative to the water exchanged by the tides despite efficient mixing within the embayment. This retention is consistent with the differential advection of surface and botton waters and the general avoidance of surface layers by the dinoflagellates. While in general agreement with the laboratory observations of Heaney \& Furnass (1980), Cullen \& Horrigan (1981) and Heaney \& Eppley (1981) for other species. these results document the species-specific response of co-occurring dinoflagellates to a variable environment and emphasize the importance of vertical movement and aggregation in the bloom dynamics of the populations in the study area.

\section{Nutrient status}

It is now well established that dinoflagellate migration patterns can be regulated by nutrients (Eppley et al. 1968, Cullen \& Horrigan 1981, Heaney \& Eppley 1981). The blooms we monitored were not mono- specific, so intracellular nutrient pools for the species of interest could not be directly measured to determine each species' nutritional status (e.g. Cullen \& Horrigan 1981). We thus relied on 2 indirect measures: (a) presence or absence of life cycle stages indicative of nutrient-limitation; (b) pattern of population development in Salt Pond during an interval spanning each of our studies.

Gonyaulax tamarensis includes a cyst stage in its life cycle, and recent laboratory studies suggest that encystment of this species occurs only when nutrients become limiting (Anderson et al. 1984, Anderson \& Lindquist 1985). Since $30 \%$ or more of the G. tamarensis cells in both 1980 and 1983 were the large planozygotes that become cysts, and since the $G$. tamarensis populations decreased rapidly during the interval our studies were conducted (Anderson et al. 1983. unpubl.), nutrient limitation is probable in both years. In contrast, no planozygotes were observed in the 1981 samples nor did the populations suddenly decline, so nutrient-sufficient conditions are assumed.

Heterocapsa triquetra does not form a zygotic cyst to our present knowledge (contrary to the earlier report of Braarud \& Pappas 1951), so its nutritional status was inferred from the population dynamics. In 1981 and 1983 the species increased at rates of 0.4 and $0.5 \mathrm{~d}^{-1}$ respectively over the $3 \mathrm{wk}$ interval spanning each study, so nutrient limitation was unlikely either year. (These are net rates that include losses due to advection and grazing, so actual growth rates would be higher.) This conclusion conflicts with our contention that Gonyaulax tamarensis was nutrient-limited in 1983, but such a difference in the nutritional status of the co-occurring species is supported by a 3 order of magnitude decrease in $G$. tamarensis cell concentrations as $H$. triquetra increased 100 -fold in the weeks spanning our study.

\section{Migration patterns}

The timing and rates of ascent and descent were similar for Heterocapsa triquetra and Gonyaulax tamarensis and in the same range as those reported for other dinoflagellates $\left(0.6\right.$ to $1 \mathrm{~m} \mathrm{~h}^{-1}$; Hand et al. 1965, Eppley et al. 1968, Heaney \& Eppley 1981). G. tamarensis exhibited 2 different migration patterns, with the major difference between the two being the maximum height or irradiance level at which vertical movement ceased. The migration of planozygotes was identical to that of the population as a whole. The nutrient-limited 1983 population aggregated at a depth where irradiance was less than half that where the nutrient-replete cells stopped vertical movement in 1981 (300 vs $800 \mu \mathrm{E} \mathrm{m}^{-2} \mathrm{~s}^{-1}$ ). The data for these $2 \mathrm{yr}$ 
are directly comparable since they were obtained with the same scalar sensor and light meter. The nutrientlimited cells in 1980 aggregated at or below $200 \mu \mathrm{E}$ $\mathrm{m}^{-2} \mathrm{~s}^{-1}$, but irradiance was measured with a flat plate or cosine collector. Measurements with a cosine collector can theoretically differ from those made with a scalar instrument by a factor of 4 in totally diffuse light (Booth 1976). However, simultaneous measurements with both instruments in Salt Pond gave scalar values generally twice those of the cosine collector at all depths (Anderson unpubl.). Thus the scalar irradiance where the $1980 \mathrm{G}$, tamarensis population ceased migrating would have been approximately $400 \mu \mathrm{E} \mathrm{m}^{-2} \mathrm{~s}^{-1}$. This again suggests that nutrient-depleted G. tamarensis cells stopped their migration lower in the water column than cells with sufficient nutrients.

The migration patterns for Gonyaulax tamarensis are similar in some respects to those reported for other dinoflagellates. Ceratium furca, $G$. polyedra, and Gymnodinium splendens all aggregated at relatively high irradiance levels when nutrients were plentiful (Cullen \& Horrigan 1981, Heaney \& Eppley 1981). Unlike these species, however, $G$. tamarensis avoided irradiance above $30 \%$ summer sunlight. When nutrient-limited, G. tamarensis aggregated at depths with irradiances 10 to $15 \%$ of surface sunlight, as was reported for G. polyedra, G. splendens (Cullen \& Horrigan 1981, Heaney \& Eppley 1981) and Ceratium hirundinella (Heaney \& Furnass 1980). Maximal growth of a Cape Cod strain of $G$. tamarensis has been reported at or above 150 to $200 \mu \mathrm{E} \mathrm{m} \mathrm{m}^{-2} \mathrm{~s}^{-1}$ in laboratory cultures growing on a 14:10 L:D cycle, with no indication of photoinhibition up to $650 \mu \mathrm{E} \mathrm{m}^{-2} \mathrm{~s}^{-1}$ (Anderson et al. 1984). Thus the nutrient-limited populations that ceased migrating at relatively low irradiances in our study would presumably have had sufficient light for growth.

Heterocapsa triquetra migrations were similar in 1981 and 1983, with cells accumulating at relatively high irradiances ( 750 to $800 \mu \mathrm{E} \mathrm{m}^{-2} \mathrm{~s}^{-1}$ ) at the maximal extent of their movement. This generally kept the cells 1 to $2 \mathrm{~m}$ below surface, except on the second day of the 1983 study when $30 \%$ of the population aggregated in the top meter. The day was overcast, however, so the irradiance at that level was also 600 to $800 \mu \mathrm{E}$ $\mathrm{m}^{-2} \mathrm{~s}^{-1}$. The population development in Salt Pond suggests nutrient-sufficient conditions for $H$. triquetra in both years, so this species can be grouped with those that aggregate high in the water column when nutrients are plentiful. Like Gonyaulax tamarensis, $H$. triquetra avoided full summer sunlight at the surface.

The differences between the behavior of Heterocapsa triquetra and Gonyaulax tamarensis in 1983 are noteworthy since the former was growing rapidly and migrating vigorously while the latter showed signs of nutrient limitation in its population development and migration. These differences could be due to speciesspecific nutritional requirements, but no data are available for comparison. The differences may also reflect reproductive strategies. Once induced, sexuality and cyst formation are probably not reversible for $G$. tamarensis, whereas $H$. triquetra could resume asexual vegetative growth rapidly if nutrients increased following a brief period of limitation. A third explanation is suggested by Eppley et al. (1968) who reported that a related species, $H$. niei (= Cachonina niei; Morril \& Loeblich 1981) continued to migrate to the surface of a laboratory tank throughout $5 \mathrm{~d}$ of nutrient starvation. Surface irradiance in that study was much lower than the natural levels in Salt Pond, but it is possible that $H$. triquetra does not alter migration behavior with changing nutrient conditions.

Both Gonyaulax tamarensis and Heterocapsa triquetra migrated to some extent under all conditions. In the shallow salt pond environment stratification does not lead to nutrient-depleted surface waters and higher concentrations at depth (Fig. 2), so migration is probably not linked to nutrient uptake at depth. Others have documented the cessation of dinoflagellate vertical movement at steep salinity or temperature gradients (e.g. Seliger et al. 1970, George \& Heaney 1978, Tyler \& Seliger 1981), but the gradients we measured were quite small. The simplest explanation is that the cells moved to the depth where they could satisfy photosynthetic requirements without photoinhibition. The upper limit for the 2 species may be near $800 \mu \mathrm{E}$ $\mathrm{m}^{-2} \mathrm{~s}^{-1}$, typically available 1 to $2 \mathrm{~m}$ below the surface.

\section{Population transport}

The dominance and localization of dinoflagellates within estuarine embayments like the Cape Cod salt ponds has been attributed to several factors including inefficient tidal flushing that would allow slow-growing species and their encysted stages to accumulate (Anderson \& Wall 1978, Anderson \& Morel 1979). The combined effects of shallow inlet channels and density stratification was thought to reduce tidal renewal of the deeper layers of the ponds. Our results demonstrate quite the opposite - that tidal mixing is very efficient and that the cells would be flushed from Salt Pond in the absence of a behavior-related retention mechanism. In the 1983 study, dye concentrations within Salt Pond decreased at a rate of $0.46 \mathrm{~d}^{-1}$ which is essentially the same as the maximum exchange rate calculated from tidal volumes (Table 1). The principal cause of this mixing efficiency appears to be an estuarinelike circulation in which flood-tide waters sink and vertically displace less dense pond water which is then 
removed with the subsequent ebb tide. Springs or groundwater provide the freshwater that keeps the pond more brackish than the incoming tidal flow.

The 1983 dye profiles clearly demonstrate that the flood-tide water crossed the inlet sill and sank below the surface layer. The same pattern was seen in 1981 when the salinity increased at depth with each flood tide (Fig. 4 C). That the shallow sill at the inlet restricted outflow to surface waters is seen in the systematic fluctuation of inlet salinities with flood and ebb tides (Fig. 4 B) and in the small loss of dinoflagellates when ebb tide occurred during the night when the populations were well below the surface (Table 1). Furthermore, in the 1983 study, inlet dye concentrations during the first ebb tide were 0.3 to $0.4 \mathrm{ppb}$, the same as the surface waters at Station 1 (Fig. 5). Dye concentrations at $2 \mathrm{~m}$ and below were double these values throughout ebb tide, so it is clear that outflowing water was from the surface. Selective outflow of surface waters and efficient tidal mixing were also observed in a different Cape Cod salt pond (Garcon et al. unpubl.)

If Gonyaulax tamarensis or Heterocapsa triquetra behaved like passive, neutrally-buoyant particles, advective population losses would be on the order of $0.5 \mathrm{~d}^{-1}$. Added to grazing mortality, the total loss would preclude bloom formation since the maximum specific growth rates of Cape Cod strains of $G$. tamarensis and $H$. triquetra are 0.4 and $0.7 \mathrm{~d}^{-1}$ respectively (Watras et al. 1982, Anderson unpubl.). Blooms of both species do occur, however, occasionally reaching red-tide proportions. The obvious conclusion is that the dinoflagellates' swimming behavior restricts advective losses to manageable levels. The organisms have sufficient motility to maintain a non-well-mixed distribution in the presence of efficient tidal mixing, and their avoidance of surface waters under sunny conditions keeps them below the layer that is removed with each ebb tide. The magnitude of this selective retention is seen in Table 1 which shows population losses of only 0.02 to $0.13 \mathrm{~d}^{-1}$ for both species. This is not an artifact of a fortuitous phasing between ebb tides and the maximal vertical height of the migration since population losses were small even when ebb tides occurred near midday $(1980,1983)$. With advective losses of this magnitude, reasonable population growth rates should allow the dinoflagellates to increase in abundance as non-motile phytoplankton are washed out at a high rate.

Seliger et al. (1970) studied populations of Pyrodinium bahamense in Oyster Bay, Jamaica and drew a similar conclusion - that in the absence of an accumulation mechanism, $P$. bahamense should be flushed from the bay. The retention mechanism that was proposed was based on a well-stratified water column that restricted mixing, the subsurface accumulation of $P$. bahamense, and the differential advection of surface waters due to wind stress. Similar patterns have been observed in freshwater lakes (Heaney \& Talling 1980) and in large estuaries (Tyler \& Seliger 1978, 1981). The scenario for the Cape Cod salt ponds is quite different in comparison, since strong stratification is not necessary for retention. In fact, the stratification of Salt Pond is the principal cause of an efficient tidal mixing process that the cells must counteract through their swimming behavior. The most important factors are the avoidance of high-irradiance surface layers by the dinoflagellates, the physical restriction of ebbing waters by the inlet sill, and the input of freshwater from springs to maintain the salinity difference between the pond and incoming flood tide waters.

One reason these salt ponds have received so much study is that they represent the source for toxic Gonyaulax tamarensis populations in the region (Anderson \& Wall 1978, Anderson et al. 1982b). Unlike northern New England where coastal blooms of this species are common (Yentsch 1984), blooms on Cape Cod seem to develop within localized embayments and spread slowly to adjacent estuaries (Anderson et al. 1982b). Our data document the 'point-source' nature of $G$. tamarensis blooms at one of these locations and explain the underlying behavioral and hydrographic mechanisms for retention. The results also suggest that advective population losses would be smallest on sunny days with flood tides during midday hours, and largest during periods with overcast skies and low surface irradiance. Since nutrient-sufficient cells aggregate closest to the surface, the largest population losses would generally introduce actively-growing, vigorous cells to nearby waters. In 1981, for example, the daily G. tamarensis loss was the highest $(12.8 \%)$ and that was the year nutrients appeared to be nonlimiting. Conversely, as a bloom matures and nutrients are depleted, advective losses should diminish as the cells limit the height of their vertical movement still further. Planozygote migration does not differ from that of the remainder of the nutrient-limited population, so cysts would be deposited within the embayment and not be widely dispersed. These inferences are consistent with the regional distribution of $G$. tamarensis cysts which are found in high concentrations in the sediments of many salt ponds but are generally scarce in adjacent waters (Anderson et al. 1982a, b).

It is evident from this study and others that the vertical migration of dinoflagellates is a complex phenomenon that can have a number of major impacts on local population dynamics. Our data emphasize the species-specific differences in the migration patterns of co-occurring organisms and emphasize the importance of surface avoidance in limiting advective trans- 
port of cells from the study area. The results are most relevant to estuarine blooms of Gonyaulax tamarensis and Heterocapsa triquetra, but the insight gained should be useful in understanding the dynamics of blooms of these species in coastal waters where monitoring discrete populations is logistically more complex.

Acknowledgements. This research was supported in part by the Department of Commerce, NOAA National Sea Grant Program through grants NA83AA-D-00049 (R/B-41) and NA84AA-D-00033 (R/B-56) to the Woods Hole Oceanographic Institution, and in part by the Ocean Assessments Division, Office of Oceanography and Marine Services (NOAA) through grant NA81RA-D-00012. We thank D. Kulis, J. Lively, V. Garcon, J. McCarthy, and S. Chisholm for assistance and extend special thanks to $\mathrm{H}$. Lind for his efforts to facilitate the field program.

\section{LITERATURE CITED}

Anderson, D. M., Aubrey, D. G., Tyler, M. A., Coats, D. W. (1982a). Vertical and horizontal distributions of dinoflagellate cysts in sediments. Limnol. Oceanogr. 27 : $757-765$

Anderson, D. M., Chisholm, S. W., Watras, C. J. (1983). The importance of life cycle events in the population dynamics of Gonyaulax tamarensis. Mar. Biol. 76: 179-190

Anderson, D. M., Kulis, D. M., Binder, B. J. (1984). Sexuality and cyst formation in the dinoflagellate Gonyaulax tamarensis: Cyst yield in batch cultures. J. Phycol. 20: $418-425$

Anderson, D. M., Kulis, D. M., Orphanos, J. A., Ceurvels, A. R. (1982b). Distribution of the toxic red tide dinoflagellate Gonyaulax tamarensis in the southern New England region. Estuar. coast. Shelf Sci. 14: 447-458

Anderson, D. M., Lindquist, N. L. (1985). Time-course measurements of phosphorus depletion and cyst formation in the dinoflagellate Gonyaulax tamarensis Lebour J. exp. mar. Biol. Ecol. 85: 1-13

Anderson, D. M., Morel, F. M. M. (1979). The seeding of two red tide blooms by the germination of benthic Gonyaulax tamarensis hypnocysts. Estuar. coast. mar. Sci. 8: 279-93

Anderson, D. M., Wall, D. (1978). The potential importance of benthic cysts of Gonyaulax tamarensis and Gonyaulax excavata in initiating toxic dinoflagellate blooms. J. Phycol. 14: 224-234

Booth, C. R. (1976). The design and evaluation of a measurement system for photosynthetically active quantum scalar irradiance. Limnol. Oceanogr. 21: 326-336

Braarud, T., Pappas, I. (1951). Experimental studies on the dinoflagellate Peridinium triquetrum (Ehrenberg) Lebour. Norse Vidensk-Akad. Oslo. Avh. I. Mat. Naturv. Klasse. No. $2,1-23$

Cullen, J. J., Horrigan, S. G. (1981). Effects of nitrate on the diurnal vertical migration, carbon to nitrogen ratio, and the photosynthetic capacity of the dinoflagellate Gymnodinium splendens. Mar. Biol. 62: 81-89

Eppley, R. W., Harrison, W. G. (1975). Physiological ecology of Gonyaulax polyedra, a red water dinoflagellate off southern California. In: Lo Cicero, V. R. (ed.) Toxic dinoflagellate blooms. Proc. lst. Int. Conf., Mass. Sci. and Technol. Found. Wakefield, p. 11-22

Eppley, R. W., Holm-Hansen, O., Strickland, J. D. H. (1968).
Some observations on the vertical migration of dinoflagellates. J. Phycol. 4: 333-340

Forward, R. B. (1976). Light and diurnal vertical migration: photobehavior and photophysiology of plankton. Photochem. Photobiol. Rev. 1: 157-209

George, D. G., Heaney, S. I. (1978). Factors influencing the spatial distribution of phytoplankton in a small productive lake. J. Ecol. 66: 133-155

Hand, W. G., Collard, P. A., Davenport, D. (1965). The effects of temperature and salinity change on swimming rate in the dinoflagellates Gonyaulax and Gyrodinium. Biol. Bull. mar. biol. Lab., Woods Hole 128: 90-101

Harris, G. P., Heaney, S. I., Talling, J. F. (1979). Physiological and environmental constraints in the ecology of the planktonic dinoflagellate Ceratium hirundinella. Freshwat. Biol. 9: 413-428

Heaney, S. I. (1974). A pneumatically-operated water sampler for close intervals of depth. Freshwat. Biol. 4: 103-106

Heaney, S. I. (1976). Temporal and spatial distribution of the dinoflagellate Ceratium hirundinella O. F. Muller within a small productive lake. Freshwat. Biol. 6: 531-542

Heaney, S. I., Eppley, R. W. (1981). Light, temperature and nitrogen as interacting factors affecting diel vertical migrations of dinoflagellates in culture. J. Plankon Res. 3: $331-344$

Heaney, S. I., Fumass, T. I. (1980). Laboratory models of diel vertical migration in the dinoflagellate Ceratium hirundinella. Freshwat. Biol. 10: 163-170

Heaney, S. I., Talling, J. F. (1980). Dynamic aspects of dinoflagellate distribution patterns in a small productive lake. J. Ecol. 68: 75-94

Holmes, R. W., Williams, P. M., Eppley, R. W. (1967). Red water in La Jolla Bay, 1964-1966. Limnol. Oceanogr. 12: 503-512

Hulburt, E. M. (1956). The phytoplankton of Great Pond, Massachusetts. Biol. Bull. mar. biol. Lab., Woods Hole 110: $157-168$

Kamykowski, D., Zentara, S. (1977). The diurnal vertical migration of motile phytoplankton through temperature gradients. Limnol. Oceanogr. 22: 148-151

MacIsaac, J. J. (1978). Diel cycles of inorganic nitrogen uptake in a natural phytoplankton population dominated by Gonyaulax polyedra. Limnol. Oceanogr. 23: 1-9

Morrill, L. C., Loeblich, III, A. R. (1981). A survey for body scales in dinoflagellates and a revision of Cachonina and Heterocapsa (Pymhophyta) J. Plankton Res. 3: 53-65

Schrey, S. E., Carpenter, E. J., Anderson, D. M. (1984). The abundance and distribution of the toxic dinoflagellate, Gonyaulax tamarensis, in Long Island Estuaries. Estuaries 7: $472-477$

Seliger, H. H., Carpenter, J. H., Loftus, M., McElroy, W. D. (1970). Mechanisms for the accumulation of high concentrations of dinoflagellates in a bioluminescent bay. Limnol. Oceanogr. 15: 234-245

Strickland, J. D. H., Parsons, T. R. (1972). A practical handbook of seawater analysis. Bull. Fish. Res. Bd Can. 167

Taylor, F. J. R. (1979). The toxigenic Gonyaulacoid dinoflagellates. In: Taylor, D. L., Seliger, H. H. (ed.) Toxic dinoflagellate blooms. Proc. 2nd Int. Conf. Elsevier/North Holland, New York, p. 47-56

Tyler, M. A., Seliger, H. H. (1978). Annual subsurface transport of a red tide dinoflagellate to its bloom area: water circulation patterns and organism distributions in the Chesapeake Bay. Limnol. Oceanogr. 23: 227-246

Tyler, M. A., Seliger, H. H. (1981). Selection for a red tide organism: physiological responses to the physical environment. Limnol. Oceanogr. 26: 310-324 
Watras, C. J., Chisholm, S. W., Anderson, D. M. (1982). Regulation of growth in an estuarine clone of Gonyaulax tamarensis: Salinity-dependent temperature responses. J. exp. mar. Biol. Ecol. 62: 25-37
Yentsch, C. M. (1984). Paralytic shellfish poisonning: an emerging perspective. In: Regalis, E. P. (ed.) Seafood toxins. American Chemical Society (ACS) Symposium Series No. 262. Wash. D. C., p. 9-24

This paper was submitted to the editor; it was accepted for printing on June 2, 1985 